\title{
Verbal Humor: a Salient Case in Translation and Translatability
}

\author{
A. Effendi Kadarisman \\ Department of English-Universitas Negeri Malang \\ Jl. Semarang 5 Malang. E-mail: achmad.effendi.fs@um.ac.id
}

\begin{abstract}
This article aims to answer the following research question: are jokes and puns translatable? Using a linguistic approach and collecting relevant data (i.e., jokes and puns in Indonesian and English), this article tries to investigate their translatability. A thorough linguistic analysis shows that there are two kinds of verbal humor: logic-twisting humor and ambiguity-manipulating humor. Verbal humor of the first type is in general translatable; for the translation is an act of rendering meaning. Conversely, verbal humor of the second type is typically untranslatable; for the translation is an act of rendering double correspondence: both form and meaning.
\end{abstract}

Key Words: humor translation, jokes and puns, (un)translatability, arbitrariness principle

\begin{abstract}
Abstrak: Artikel ini bertujuan menjawab pertanyaan penelitian: apakah lelucon dan permainan-kata dapat diterjemahkan? Dengan menggunakan ancangan linguistik dan mengumpulkan data yang relevan (berupa lelucon dan permainan-kata dalam bahasa Indonesia dan bahasa Inggris), tulisan ini mencoba menjajagi kadar keterjemahan humor. Hasil analisis linguistik menunjukkan bahwa humor ada dua jenis: permainan logika dan permainan ambiguitas. Humor jenis pertama gampang diterjemahkan, karena penerjemahannya merupakan upaya alih-makna. Sebaliknya, humor jenis kedua tak bisa diterjemahkan, karena upaya alih-bentuk-dan-makna sekaligus merupakan upaya yang mustahil.
\end{abstract}

Kata kunci: terjemahan lelucon, lelucon dan permainan-kata, ketidakterjemahan, prinsip arbitrer

If you read Attardo's (1994) Linguistic Theories on Humor, you are not supposed to expect to find this book funny. In fact, this book dissects humor in a dead serious way. Raskin's (2008) introductory chapter to his The Primer of Humor Research is a bit humorous; in several places of this essay he occasionally quips and flips around. Following Raskin, I would like to investigate humor and proceed doing so in a somewhat jocular way too. Most of us are probably familiar with "Laughter, the Best Medicine," a rubric in Reader's Digest. If you push further, you will find it true that laughter is indeed the best medicine. But if you laugh with no reason, you need medicine.

When linguists propose theories of humor, they do not mean to present theories of laughter: how you should laugh or giggle. Also, as noted earlier, none of these theories are funny. A good summary of humor theories is presented by Attardo (2008), distinguishing them into three categories: (a) release theory, (b) hostility or superiority theory, and (c) incongruity theory.
Instead of presenting a definition of each theory, let me provide you with illustrative examples:

(1) He is a man of letters. He works at the Post Office.

(2)In terms of the neural system of their brain, people fall into two categories: right-brain persons and leftbrain persons. Barrack Obama is a right-brain person; and Donald Trump is a wrong-brain person.

(3)A student came over for a visit to his professor of philosophy. To his surprise, he found the professor working by his own, building a sidewalk in front of the house. Suddenly some children in the neighborhood came up, running around and stomping on the wet sidewalk. Infuriated, the professor chased them and cursed vehemently. The student was shocked at the display of such behavior. "Sir, I thought you loved children." "In the abstract, yes. But on the concrete, no."

If the first joke succeeds in making you smile or laugh, then it serves as an example for release theory. Your smile or laughter may make you feel relieved. 
The second joke is an example for hostility or superiority theory. When you laugh at the joke, it is because you enjoy its hostility toward Donald Trump, and at the same time you feel superior to him. And the third joke, presenting itself as an incongruous text, is an example for congruity theory. The answer given by the professor takes you by surprise: it is a logical trap, not a logical response to the student's question.

However, if you examine each of the three jokes carefully, you will see that all of them belong to incongruous discourse. As pointed out by Norrick (2003), it is the sudden perception of incongruity that triggers laughter (emphasis mine). Referring to example (1), the phrase "a man of letters" initially means 'a literary person'. But the next sentence "He works at the Post Office" changes the meaning abruptly into 'a person who delivers letters'. The punch-line, or the last part of the joke that makes it funny, allows you to simultaneously perceive an object within two contrasting frames of reference. In other words, as seen from a linguistic perspective, the inner structure of jokes may be made explicit by referring to incongruity theory. This is the gist of Raskin's (1985) Semantic Script Theory of Humor, which represents the set-up and the punch-line of a joke in a formal notation.

Now let us take a close look at each verbal joke above. What is the source of hilarity or funniness? Each joke manipulates lexical ambiguity, or more precisely, homonymy: a word spelled the same, pronounced the same, but having different meanings. The word "right" in (2), for example, can be the opposite of "left" or "wrong". Note that manipulating homonymy to create humor is part of pun, which belongs to the so-called wordplay.

Can we translate the three jokes above into Indonesian? Literally, the translation is possible; but the humor will get lost in Indonesian. To illustrate, let us translate the dialogue at the end of joke (3), and put the free translation as (4).

(4) "Saya kira Bapak mencintai anak kecil" "Da-

lam gagasan ya, tapi di semen yang basah tidak."

Instead of producing verbal humor in Indonesian, the translation produces a bizarre text - a strange text that lacks coherence.

Why does the humor get lost? Homonymy is almost always language-specific. That is, a homonym in English is most probably not a homonym in Indonesian - and vice versa. As a comparison, look at the homonymous word buku manipulated in the following joke.
(5) 'Buku” dapat berarti 'kitab' atau 'ruas'. Anda para mahasiswa adalah binatang berbuku-bu$k u$, karena punya banyak buku atau kitab.

Just as English jokes manipulating homonymy are not translatable into Indonesian, the same jokes in Indonesian, such as example (5), are equally untranslatable into English.

And yet, this paper intends to pursue this issue further. Some of you might be familiar with political humor which was popular during the 1980s - almost four decades ago. The most popular during that era was Mati Ketawa ala Rusia. This small book contained verbal jokes making fun of Russian authoritarian politics. When you do googling, you will find its English version: Russians Die Laughing. Very probably, the English version is a result of translating the Russian original. This tells us that verbal humor is translatable.

Moreover, there has been some research on humor translation. (At this point I cannot avoid being serious.) Attardo (2008) states that humor translation is extremely difficult, or perhaps even impossible. As such, in the dubbing of films and sitcoms, the translators have tried to surmount the difficulties by using numerous strategies. "These range from pragmatic translation (i. e., keeping the humor, but abandoning the sense of the original text), to simply ignoring the humor and perhaps replacing it with another joke, even elsewhere in the text (p. 126-7).

The study on humor translation by Chiaro (2008) is probably most comprehensive. She compares humor translation with poetry translation, both being arduous tasks which require rendering both form and meaning simultaneously. Moreover, with respect to word-play, she states that "puns, a common feature in jokes, are notoriously untranslatable" (p. 571). The chances of finding the same type of pun in the target language (TL) are almost none. This leads to four translation strategies: (a) leaving the pun unchanged in the source language (SL), (b) replacing the SL pun with a TL pun, (c) replacing the SL pun with an idiomatic expression in the TL, or (d) ignoring the pun altogether ( $\mathrm{p}$. 592).

Last, a study by Natarina (2012) focused on investigating the translation of puns in the movie Goldmember. While results of data analysis (p. 167-9) show that 10 out of 30 puns in English (33\%) were translatable into puns in Indonesian, the discussion of research findings was very sketchy. Only one illustrative example is presented, discussed under a lengthy reference to Hallidyan linguistic theory. As such, this research contributes very little to humor translation. 
Partly convinced by Chiaro's (2008) findings, the present study raises a general research question: is verbal humor translatable? More specifically, are jokes and puns translatable? It should be noted that jokes and puns here are presented as loose verbal humor, each of them standing by itself, not framed within a larger discourse context.

\section{METHOD}

This research is descriptive qualitative in nature; for its primary purpose is to find out the (un)translatability of jokes and puns (see Berg, 1995 and Lincoln \& Guba, 1985). The relevant data were collected from all possible sources: printed and electronic. Electronic data are obtained from the Internet as well as social media, especially jokes and puns floating around on WhatsApp. Five jokes (containing no pun) were selected and translated, two of them from Indonesian to English and three of them from English to Indonesian. The results were five jokes in free translation (see Appendix 1), put in a questionnaire and sent out via WhatsApp to first-year ELT students at School of Graduate Studies at Universitas Negeri Malang, to judge whether or not the jokes were funny. As noted in the record, 33 out of 35 students responded to the questionnaire. Results of data analysis in the form of frequencies and percentages will be discussed in the next section.

As for puns, as "tested" in example (4) above, it is very clear that most probably they are not translatable. Therefore, translating puns and asking for "hilarity judgment" would be futile. It would be like asking a question for the obvious answer.

\section{RESULTS AND DISCUSSION}

A joke is something you say to cause amusement or laughter; it can be very short, well-known as a oneliner. Recall that even a one-liner contains a punchline: the last expression (a word, a phrase, or a sentence) that makes the joke funny. In terms of discourse structure, one-liners can take several forms: (a) a definition, (b) a very brief story, or (c) a onequestion and one-answer dialogue, as shown by the following pairs of examples in Indonesian and in English.

(6)Mamalia adalah ibu dari seorang anak perempuan bernama Lia.

(7) A mailman is an ideal husband for a female woman.
(8) Hampir seharian polisi melakukan olah TKP; padahal mereka nggak tahu apa bumbunya.

(9)A bump came to me and said he had not had a bite for weeks; and so I bit him.

(10) "Binatang apa yang paling bodoh?" "Cicak, karena kamu tanya apa saja, dia cicak tahu."

(11) "Tell me your name and education." "I graduated from Yale. My name is Yohnson."

As you may vaguely perceive, all of these jokes rely on word-play. Let me make them clear to you. In (6), the mono-morphemic word mamalia (cf. mammal in English) is broken down into two morphemes: mama and Lia. In (7), mailman is a homophone, treated as male man. In (8), the idiom olah TKP (investigating the crime scene) is treated literally, to mean 'cooked TKP' - which is nonsense. In (9), the idiom had not had a bite (had not eaten anything) is also treated literally, had not got a bite. In (10), cicak (lizard) is a paronym, treated as tidak (no). In (11) Yale and Yohnson are also paronyms, intended to refer to 'jail' and 'Johnson'. Notice that homophony in (7) and paronymy in (10) and (11) belong to pun: manipulation of ambiguity at the phonological level, whereas 'morphemic break' in (6) and treating idioms literally in (8) and (9) are instances of manipulating ambiguity at the lexical level.

Keep in mind that the key term here is "manipulation of linguistic ambiguity", which may occur at any structural level. If a joke is a result of manipulating linguistic ambiguity, then it belongs to language-specific humor. Consequently, the joke works only within that particular language; it is untranslatable. The explanation goes back to Saussure's (1916 [1959]) arbitrary principle. That is, the same concept (better known as meaning or more technically signified) shows up as different expressions (bettern known as forms or signifiers) across languages. The homophony mailman vs. male man in (7) is English-specific, just as the paronymy cicak vs tidak in (10) is Indonesian-specific. If you translate mailman into pak-pos in Indonesian, or cicak into lizard in English, then the homonymy and paronymy are gone. More generally, your translation makes the ambiguity get lost; and so the humor gets lost too.

In contrast, if jokes contain no pun, then they are translatable. Consider the following pairs of examples: the original jokes along with their translations.

(12) What is the difference between electricity and lightning? Well, you don't have to pay for lightning. (13) Apa bedanya listrik dengan kilat? Klo kilat, kamu nggak usah bayar rekening. 
(14) "Waiter, is it tea of coffee? It tastes like kerosene!" "That is our tea, Sir. Our coffee tastes like gasoline."

(15) "Mas, ini teh apa kopi? Rasanya kayak minyak tanah!” "Oh, itu teh, Pak. Klo kopi di sini rasanya kayak bensin."

(16) Kenapa kerbau tidak bersayap? Kamu kejatuhan tahi burung aja sudah marah-marah. Bagaimana kalau kerbau bisa terbang ...?

(17) Why don't buffaloes have wings? Even bird droppings make you furious. What if buffaloes fly up in the sky ...?

Now you should probably be aware that there is no pun involved; each joke is simply a result of twisting logic. Following Raskin and Attardo (1994), as cited in Norrick (2003, p.1334), let us take a close look at the original jokes in (12), (14), and (16). Our close examination should reveal that each joke results from a logical twist through an unexpected move: the move from the essential to the trivial in (12), from the usual to the bizarre in (14), and from the natural to the unnatural in (16). All of these moves can be seen as universal features within our general ways of reasoning; they belong to us the human race (not the horse race), and they operate in any language. Accordingly, jokes (12) and (14) are translatable from English into Indonesian, and joke (16) is translatable from Indonesian into English. The translation here simply renders the meaning or signified from the SL to the TL, without any reliance on the form or signifier. Again, the explanation goes back to the principle of arbitrariness.

At this point, I would like to invite you to take a look at the translated jokes as mentioned in the "Method" section. Referring to Appendix 1 and Table 1, jokes (1) and (2) were originally in Indonesian; and I translated them freely into English. Jokes (3), (4), and (5) were originally in English, and I translated them freely into Indonesian. The free translation (see Newmark, 1981) was chosen so as to produce the "closet natural equivalents", i.e., jokes which sound natural in the TL as they do in the SL. Then I put the five jokes in free translation in a questionnaire and sent them out to the respondents for "hilarity or funniness judgment" (see the Method section for detailed information). Results of their judgments are presented in Table 1.

As you can see in Table 1, the degree of hilarity or funniness of each joke is shown by the percentage. It was obtained through the following formula: $F / \Sigma x$ $100 \%$, where $\mathrm{F}=$ funny judgments, and $\Sigma=$ the total number of respondents (i.e., 33). The percentages tell us that joke (3) is fairly funny (66.6); jokes (1) and (4)
Table 1. Results of Hilarity Judgment

\begin{tabular}{cccc}
\hline Joke & Funny & Not Funny & Percentage \\
\hline 1 & 23 & 10 & 69.7 \\
2 & 30 & 3 & 90.9 \\
3 & 22 & 11 & 66.6 \\
4 & 23 & 10 & 69.7 \\
5 & 27 & 6 & 81.8 \\
\hline
\end{tabular}

are funny (69.7); joke (5) is quite funny; and joke (2) is very funny. The different degrees of hilarity owe to the respondents' familiarity. The jokes which are familiar to them are no longer funny, whereas those which are new to them sound funny. While the five jokes have different degrees of hilarity, all of them may be characterized as "funny". This tells us that that the translation succeeds - another way of saying that the jokes are translatable.

For better clarity, let me pick up jokes (1) and (3) for you, each presented in the translated and original version.

(18) Joke 1-translated version
A: Wow! A new cell phone?!
B: Yup!
A: Where did you get it?
B: I won a running competition.
A: Really? Who were the participants?
B: A cop, the phone owner, $n$ me.

(19) Joke 1-original version
A: Handphone baru ya?
B: Emang.
A: Dapet dari mana lu?
B: Lomba lari.
A: Masak sih. Siape aja pesertanya?
B: Gue, polisi, ama yang punya HP.

The set-up of joke (1) leads you to think that B just bought a new cell phone. But the punch-line gives you a surprise: it was a 'grabbed phone'. Here you see the sudden logical move: from the normal to the abnormal.

(20) Joke 3 - translated version: $\mathrm{P}=$ pasien, $\mathrm{D}=$ dokter

P: Dokter, apakah saya menderita amnesia? Sy lupaaa terus. Jadi pelupa berat. Apa yang harus saya lakukan, Dokter?

D: Coba diingat-ingat, kapan Anda mulai merasakan munculnya penyakit ini?

P: Penyakit apa, Dokter?

(21) Joke 3-original version: $\mathrm{P}=$ patient, $\mathrm{D}=$ doctor

P: Doctor, I'm afraid I'm suffering from amnesia. I'm forgetting everything. What should I do?

D: When did you start having this problem?

P: What problem? 


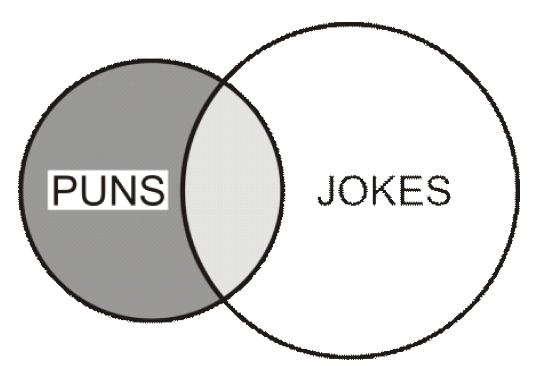

Figure 1. Puns and Jokes, Overlapping

Again, when you read the set-up of joke (3), you would expect that the patient will give an account of when he started suffering forgetfulness. However, the punch-line gives you a sudden twist: he totally forgot everything, not even remembering what he said a few seconds ago. It is another sudden move from the normal to the bizarre.

This far, I hope, you have grasped the inner structures of puns and jokes. Puns as word-play are always language-specific. As for jokes, they may rely on puns or simply rely on a sudden twist of logic. Just like puns, jokes of the first type become language-specific; but jokes of the second type belong to general discourse. Visually, puns and jokes may well be represented by Figure 1. As shown in this figure and related to translatability, puns being language-specific (in dark grey) are not translatable. Similarly, jokes which rely on puns (in light-grey) are not translatable either. This finding reaffirms the result of previous research by Chiaro (2008): puns are notoriously untranslatable. In contrast, jokes which rely on a sudden twist of logic (in white) are in general translatable. In short, the translatability and untranslatability of verbal humor is determined by the way how meaning and form get interrelated across different languages.

\section{CONCLUSION}

Verbal humor takes you by surprise and brings you to laughter. It does so in two possible ways: (a) through a pure twist of logic or (b) by twisting logic with the aid of manipulating linguistic ambiguity. Logictwisting humor is in general translatable, whereas ambiguity-manipulating humor is most probably untranslatable. The former yields to translation, for the act of translating simply renders meaning or signified. But the latter stays away from translation; for it requires the rendering of both form and meaning, or signifier and signified. In this respect, humor translation, much like poetry translation (see Kadarisman, 2011), requires preserving double correspondence (Barbaresi, 2002, p. 121), that is, keeping both form and meaning of the SL text in the translation.

The present investigation of jokes and puns translation along with the research findings leads us back to the nature of human language and the basic function of translation. Whatever can be expressed in one language can be re-expressed in another. This is the general rule. But there is also a specific rule: each language is unique in relating form and meaning. In effect, when a "text" relates form and meaning in a language-specific way, translation can be an arduous task, or simply an impossible act. This explanatory power of linguistics goes back to the postulate outlined by the founding father of the discipline: language is a system of arbitrary signs (Saussure, 1916, pp. 67-70).

The discussion of research findings makes it obvious that this study sheds light only on the manipulation of ambiguous structures at the phonological and lexical levels. Future research may broaden the scope by investigating how verbal humor manipulates ambiguity at the morphological, syntactic, semantic, pragmatic, and discourse levels.

\section{Acknowledgment}

I would like to thank $I b u$ Hilda Cahyani, Ph.D., a colleague at the State Polytechnic of Malang, for proofreading and suggesting improvements for the earlier draft of this paper. Any negligence or deficiency, however, is my responsibility alone.

\section{REFERENCES}

Attardo, S. (1994). Linguistic Theories of Humor. (V. Raskin, Ed.). Berlin-New York: Muyton de Gruiter.

Attardo, S. (2008). A Primer For The Linguistics of Humor. In The Primer of Humor Research (pp. 101-156). The Hague: Muyton de Gruiter.

Barbaresi, L. M. (2002). Text Linguistics and Literary Translation. In A. Reccardi (Ed.), Translation Studies: Perpectives on an Emerging Discipline (pp. 120 132). Cambridge: Cambridge University Press.

Berg, B. L. (1995). Qualitative Research Methods for The Social Sciences (Second). Boston: Allyn and Bacon.

Chiaro, D. (2008). Verbally Expressed Humor and Translation. In V. Raskin (Ed.), The Primer of Humor Research (pp. 569-608). The Hague.

Kadarisman, E. (2011). On Poetry Translation: The Impossible, The Difficult, and The Subtle. Linguistik Indonesia, Februari 2, 85-100. 
Lincoln, Y. S., \& Guba, E. G. (1985). Naturalistic Inquiry. Beverly Hills: SAGE Publications.

Natarina, A. (2012). The Strategy of Translating Puns in The English-Indonesian Subtitle of Austin Power's Gold Member. CELT, 12(2), 160-179.

Newmark, P. (1981). Approaches to Translation. New York: Special Libraries Association.

Raskin, V. (1985). Semantic Mechanism of Humor. Dordrecht -Boston-Lancaster: D.Reidel.

\section{Appendix 1. QUESTIONNAIRE}

Below are five jokes, meant as an instrument for research on verbal humor. You are requested to give "hilarity of funniness judgment" on these jokes, simply by putting $\mathrm{F}$ (funny) or NF (not funny) following each number. Then please send back to me the joke numbers $(1,2,3,4,5)$ along with your judgments: $F$ or NF. If you wish, you could also give specific comments on individual jokes, or a general comment on all the jokes. Your prompt response to this questionnaire is much appreciated.

\section{Joke 1}

A: Wow! A new cell phone?!

B: Yup!

A: Where did you get it?

$\mathrm{B}$ : I won a running competition.

A: Really? Who were the participants?

B: A cop, the phone owner, $n$ me.

Joke 2

A man riding his motorbike out of a gas station became suspicious as he was being followed by two young men on another motorbike. So he sped up to get some distance away from them. The younger riders sped up too. Then there was a furious racing between them. After a few miles, they caught him up and asked him to stop. Outraged, the man shouted, "Why did you follow me?!"

"Sir, we're afraid you forgot something at the gas station."

"What?!"

"Your wife, Sir."
Raskin, V. (2008). Theory of Humor and Practice of Humor Research: Editor's Note and Thoughts. In V. Raskin (Ed.), The Primer of Humor Research (pp. 1-15). The Hague: Muyton de Gruiter.

Raskin, V., \& Attardo, S. (1994). Non-Literalness and NonBona-Fide in Language. Pragmatics and Cognition, 2,31-69.

Saussure, F. de. (1916). Course in General Linguistics. New York-Toronto-London: McGraw-Hill Book Company.

\section{Joke 3}

P: Dokter, apakah saya menderita amnesia? Saya lupaaa terus. Jadi pelupa berat. Apa yang harus saya lakukan, Dokter?

D: Coba diingat-ingat, kapan Anda mulai merasakan munculnya penyakit ini?

P: Penyakit apa, Dokter?!

\section{Joke 4}

Guru: Andik, misalnya ayahmu pinjam uang kepada pamanmu 10 juta, tanpa bunga. Ayahmu sanggup mengembalikan 2 juta setiap bulan. Setelah 3 bulan, berapa sisa pinjaman ayahmu?

Andik: 10 juta, Bu Guru.

Guru: Andik! Kamu ini tahu matematika atau tidak?!

Andik: Maaf, Bu Guru. Ibu tahu ayah saya atau tidak ...?

\section{Joke 5}

A: Tolong, angka-angka berikut dicatat dengan baik. Anda supir bus patas jurusan SurabayaYogya, dengan dua pemberhentian: Madiun dan Solo. Waktu berangkat dari Surabaya, ada 38 penumpang. Di Madiun, 3 orang turun, dan 5 penumpang baru naik. Di solo, 12 orang turun; tidak ada penumpang baru yang naik. Pertanyaannya: Siapakah nama sopir bus patas itu?

B: Lho! Mana aku tahu?!

A: Itulah, karena tadi kurang memperhatikan. Di awal soal saya kan bilang, "Anda sopir bus patas ..." 